\title{
BAGE wt Allele
}

National Cancer Institute

\section{Source}

National Cancer Institute. BAGE wt Allele. NCI Thesaurus. Code C104493.

Human BAGE wild-type allele is located in the vicinity of $21 \mathrm{p} 11.1$ and is approximately $2 \mathrm{~kb}$ in length. This allele, which encodes B melanoma antigen 1 protein, may be involved in melanoma progression. 